\title{
Heterogeneous catalyzied FAME synthesis from renewable feedstock
}

\author{
Vitthal L. Gole ${ }^{1 *}$, Aditya Gupta1 ${ }^{1}$ Maharshi Yadav \\ ${ }^{1 *}$ Department of Chemical Engineering, Madan Mohan Malaviya University of Technology, Gorakhpur, INDIA \\ "Corresponding Author: e-mailvlgch@mmmut.ac.in.
}

\begin{abstract}
With depleting conventional energy sources there is urgent need to look for alternatives for automotive fuel especially from Non-edible feedstocks. Present work investigates FAME (fatty acids methyl esters) synthesis commonly known as Biodiesel from non-edible feedstock Karanja using heterogeneous catalyst calcium oxide $(\mathrm{CaO})$. Study was investigated considering effects of oil-methanol mole ratio, concentration of catalyst and temperature of reaction. Our results confirm that higher mole ratio was useful to enhance FAME yield. The findings of work confirm that molar ration of 1:8 was optimum for catalyst loading of $2.0 \%$ and reaction temperature of $60^{\circ} \mathrm{C}$. The maximum yield of FAME was found 92.4\%. The work confirms the FAME obtained from Karanja has a potential alternative for petro-based diesel. Novel protocol developed in present work address the issues of downstream processing of biodiesel synthesis and considerable amount of wastewater generated can be avoided.
\end{abstract}

Keywords: FAME, Non-edible Oil, Biodiesel, Synthesis

DOI: http://dx.doi.org/10.4314/ijest.v13i1.7S

Cite this article as:

Gole V.L., Gupta A., Yadav M. 2021. Heterogeneous catalyzied fame synthesis from renewable feedstock, International Journal of Engineering, Science and Technology, Vol. 13, No. 1, pp. 48-53. doi: 10.4314/ijest.v13i1.7S

Received: December 1, 2019; Accepted: February 5, 2021; Final acceptance in revised form: March 31, 2021

This paper was earlier presented at the International Conference on Energy, Environment \& Material Sciences (ICE2M), 1-3 December 2019 and substantially improved for this Special Issue. Guest Editor: Dr. Sri Niwas Singh, Professor (HAG), Department of Electrical Engineering, Indian Institute of Technology Kanpur, 208016 (U.P.) India, former Vice-Chancellor, Madan Mohan Malviya University of Technology Gorakhpur (April 2017 to July 2020).

\section{Introduction}

Energy demand in India is increasing on multi-fold basis. That too requirement of automotive fuel is increasing with globalization and changing lifestyle. Demand of petro-base diesel is increasing and estimated present crude oil demand is 90 billion metric tons per annum. Recent data released by petroleum-planning analysis wing of oil ministry of Indian government about the fuel consumption stated that demand in February 2019 was increased by $2.7 \%$ and reached to 17.5 million tons and was higher compare to previous quarter. India is meeting $80 \%$ crude oil demand through imports and large quantum of economy is spent on same (Colombo et al., 2017; Petroleum Planning and Analysis Cell All India Study on Sectoral Demand of Diesel \& Petrol, 2013; White Paper on Alternative Fuels for Vehicles Vision \& Recommendations Alternative Fuels in India, 2019). Hence, there is urgent need to explore the never/renewable sources for automotive sector.

India has targeted to reduced crude oil dependence by $10 \%$ up to 2022 . Waste cooking oil consider as a probable option for FAME synthesis, commonly known as biodiesel to achieve goal of 2022(White Paper on Alternative Fuels for Vehicles Vision \& Recommendations Alternative Fuels in India, 2019). Biodiesel synthesis from other non-renewable sources need to be explored. From the Indian context Karanja, Jatropha, Nagchampa (Calophyllum Innophyllum Linn), Neem oil are considered as possible 
bases for biodiesel synthesis. Oil obtained from these feedstocks are primarily used for medicinal purpose, but residue remain after extraction of essential product can be used for synthesis of fatty acids methyl esters (Halder et al., 2014; Patel \& Sankhavara, 2017; Takase et al., 2015). Karanja (known as pongamia pinnta) is fast rising average size tree with size of 30-40 ft and spread awning shade. It can be grown semi-arid region condition and wide range conditions of India. The different type soil such as salty, alkaline, hefty, types of soils, due this nature it can be grown all parts of India. Shrunk of Karanja is small in diameter and height is more than 1.65 meter. It has long leaves of size 5-10 cm extended and 4-7 cm widespread and organized in 2-3 pairs. Flowers are generally pea-shaped type with 15-19 mm lengthy and glowing, well-lit purple or white in color. Kernels are sunlit brown in hue with size 1-1.5 cm (Banković-Ilić et al., 2017; Halder et al., 2014; Harsha Hebbar et al., 2018; Patel \& Sankhavara, 2017; Takase et al., 2015). The physico-chemical properties of Karanja are shown in Table 1.

One tree can give $9-90 \mathrm{~kg}$ of seed pod which yields up to 35-40\% oil. Kernels of tree due content oil and yield 30-40\% oil, normal Karanja produce 8-24 kg kernels. The typical composition of air-dried kernels consists of 27-28\% oil, 17-18\% protein, 6.66.8\% starch, 7-8\% fiber and ash,2.3\% (Halder et al., 2014; Patel \& Sankhavara, 2017)

Table 1: Physicochemical Karanja lard properties

\begin{tabular}{|l|c|}
\hline \multicolumn{1}{|c|}{ Properties } & Value \\
\hline Water/moisture & $0.05 \%$ \\
\hline Explicit gravity & 0.94 \\
\hline Density & $0.94 \mathrm{~g} / \mathrm{cc}$ \\
\hline C-residue & $0.80 \%$ \\
\hline Ash & $0.05 \%$ \\
\hline Flash-point & $2120^{\circ} \mathrm{C}$ \\
\hline Fire-point & $2140^{\circ} \mathrm{C}$ \\
\hline Acid-value & 16.8 \\
\hline Iodine-value & 86.5 \\
\hline Boiling-point & $3300^{\circ} \mathrm{C}$ \\
\hline Cloud point & $20^{\circ} \mathrm{C}$ \\
\hline Caloric-value, $\left({\left.\mathrm{kcal} \mathrm{kg}^{-1}\right)}^{-1}\right)$ & 8742 \\
\hline Cetane-number & 38 \\
\hline Saponification-value & 85.7 \\
\hline Unsaponifiable-matter & $0.9 \%$ \\
\hline
\end{tabular}

Table 2: Composition of Fatty acid in Karanja lurd

\begin{tabular}{|l|l|}
\hline Fatty-acid & $\%$ \\
\hline Palmitic-acid & 11.6 \\
\hline Stearic-acid & 7.5 \\
\hline Oleic-acid & 51.6 \\
\hline Linoleic-acid & 16.6 \\
\hline Eciosanoic-acid & 1.4 \\
\hline Dosocansnoic-acid & 4.4 \\
\hline Tetrasanoic-acid & 1.1 \\
\hline Residue & 5.8 \\
\hline
\end{tabular}

Oil is essential and notable product gained from Pongamia-Pinnata which is thick, yellow-reddish-brown having calorific-value $40.8 \mathrm{MJ} / \mathrm{kg}$. Mechanical-expeller commonly employed for oil-extraction. Obtained oil is non-edible with offensive in smell. Common application oil is medicinal purpose, lamp fuel and can be potential source for biodiesel synthesis. Other applications of oil are fuel as cooking, emollient, water-paint-binder, leather-dressing, candle, tanning industries and, soap-manufacturing. Other potential applications of Karanja are body oil, lotions, creams, hair-tonics, sham-poos and, pesticides (Banković-Ilić et al., 2017; Patel \& Sankhavara, 2017). The typical composition of fatty-acid present in Karanja-oil is shown in Table 2.

Biodiesel obtained from Karanja oil has numerous advantageous such as a) good lubricating and energy source, b) renewable in nature, c) highly- bio-degradable with miinor burning toxicity, d) grown and cultivate in all parts of country, e) bust rural economy using waste and barren land, f) compare to petro-diesel gives off negligible emissions of sulphates-, aromatic-hydrocarbons with minor emission of carbon-monoxide (CO) and particulates, g) no or minor modification required for boiler and internal combustion engines, h) carbon chain consist of more numbers of oxygen which helps in controlling emission, i) modern engine can run on B100 biodiesel with minor modification in existing engines with minimum loss of engine parts with minor wearing and tearing (Dhanasekar et al., 2019; Harsha Hebbar et al., 2018; Kavitha et al., 2019; Madhu et al., 2016)

Transesterification is most commonly technique used for biodiesel synthesis. If there are large quantity of initial- free-fatty-acid (FFA) existing in oil, then acid-esterification pretreatment used for reduction of FFA content. Acid value is measure free fatty acid 
typical this value needs to be reduced below $2 \%$ to avoid saponification during alkaline transesterification. Hydrolysis- and generation of left-over by-products further hamper the reaction and product yield may be lowered significantly. It required large quantum of water for downstream-processing to remove waste and lengthier duration for reaction-completion (Banković-Ilić et al., 2017; Harsha Hebbar et al., 2018; Kavitha et al., 2019; Madhu et al., 2016) There are number of alternatives are available for feedstock with large quantum of free fatty acids which are listed below:

- Esterification using different ion exchange resins or heterogeneous catalyst

- Distillation

- Acid esterification in presence of catalyst such as sulphuric-acid, methane-sulfonic-acid, ferric-sulphate

- Neutralization using alkali- followed by soap-separation in decanter

- Use of polar-liquids for extraction with combination of acid-esterification

Major limitations associated with esterification are higher amount of chemical requirement, waste-removal and lengthierduration for reaction completion. Hence, there is urgent need to look of potential alternative for elimination of FFA in oil (Dhanasekar et al., 2019; Madhu et al., 2016). Heterogeneous catalyst can overcome the limitations associated with acid esterification followed by transesterification. Major advantage associated with this heterogeneous catalyst to reduced wastewater generation for downstream processing. Calcium oxide is one better option as heterogeneous catalyst for biodiesel synthesis (Banković-Ilić et al., 2017; Harsha Hebbar et al., 2018; Kavitha et al., 2019; Madhu et al., 2016). It is commonly obtained from waste such as eggshells and mollusk shell.

Present work investigate FAME synthesis from Karanja. Process parameters such as oil-methanol mole- ratio, catalyst concentration and temperature of reaction. Analysis of product was carried out using HPLC (High-performance liquidchromatography).

\section{Materials-Method}

\subsection{Materials}

Raw Karanja oil was procured from Pune local market. Fatty-acid oil-composition is shown in Table 2. Methanol(HPLC grade), Sulfuric acid (98\%), Hexane(HPLC grade), and Calcium Oxide was obtained from M/s New-neeta, Chemicals, Pune. HPLC internal-standards viz methyl-linoleate and methyl-oleate was received gift from ICT, Mumbai.

\subsection{Reactor}

The reaction was carried out in $5.21 \mathrm{~cm}$ (ID) and $160 \mathrm{cu} \mathrm{cm}$ volume. Glass-reactor fortified with reflux-condenser.Reactor temperature was maintained by keeping glass reactor in constant temperature bath. Water bath is made of M/s Medico Instruments, Mumbai and temperature of reactor can regulated within $\pm 2^{\circ} \mathrm{C}$. Pitch type of blade-glass stirring having 1.2 inches dia- was used to attain even mixing reactants. Experimental setup representation is desiccated in Figure 1.

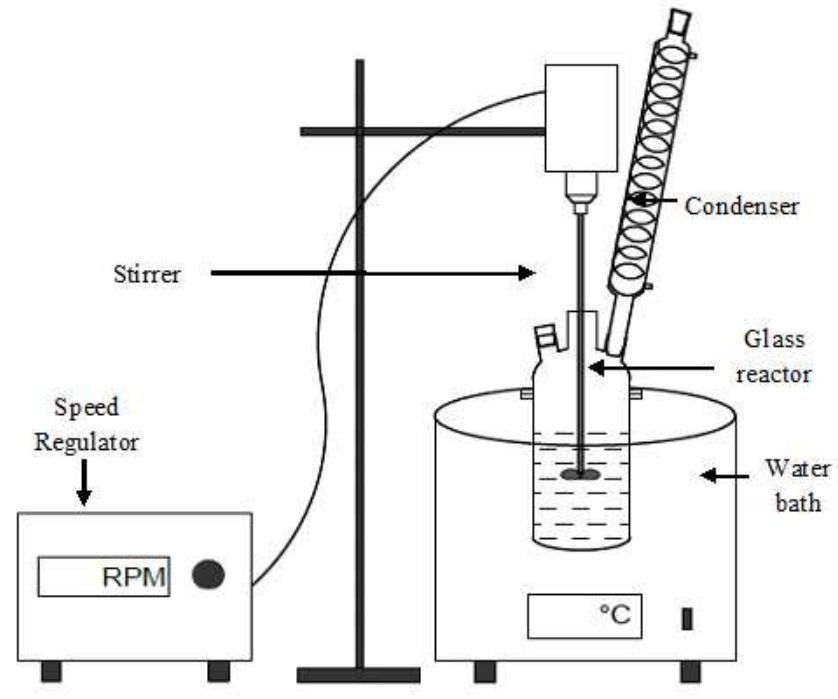

Figure 1: Schematic of experiment Set up

$90 \mathrm{~mL}$ of Karanja-oil was placed in reactor and preheat to $110^{\circ} \mathrm{C}$ to remove initial moisture-content oil and was observed using Karl-Fisher-Titration Unit. For preparation of calcium oxide and was heated for known temperature of $700^{\circ} \mathrm{C}$ for $4-5$ hrs to remove volatile matter and moisture using Muffle furnace. Heated oil cooled to $60^{\circ} \mathrm{C}$ was mixed with known quantity of calcinated calcium oxide and methanol was added. Reaction mixture was heated, and samples were withdrawn at regular of time followed 
quick quenching in ice bath to kill reaction. Cooled samples were transferred to separating funnel. Lower layer consist of heterogenous catalyst and glycerol was detached. Upper-layer consists of FAME was eroded with hot distilled water to remove catalyst-traces and other impurities. Sample was heated under vacuum in rotary vacuum evaporator to remove traces of moisture. Further quantification of FAME was verified using HPLC.

2.3 Analysis

Transesterification samples were analyzed using HPLC (Hitachi) with C18 Phenomenex-column $(25 \mathrm{~cm} \times 4.6 \mathrm{~mm}, 5 \mu \mathrm{m}$ particlesize) using UV-visible detection at $210 \mathrm{~nm}$. Lined elution of methanol- and -hexane was maintained for analyzing samples. The mobile-phase contains of $90 \%$ methanol- and $10 \%$ hexane- and flowrate of $1 \mathrm{ml} \mathrm{min}^{-1}$. Sample was prepared by using $10 \mu \mathrm{l}$ of sample diluted-with $10 \mathrm{~mL}$ of methanol. Calibration curve was prepared using internal-standards of methyl-linoleate and methyloleate known concentration and area under the curves. Concentration of unknown samples were calculated calibration curve.

\section{Results and Discussion}

Calcium oxide has hydro-philic nature and remains in methanol-phase. Methoxy ions are generated on surface of catalyst. Ions generations results of methanol molecule adsorption and subsequent transfer to organic-phase at the crossing point between the two-phases and reaction progress. Progress of reaction in presence of $\mathrm{CaO}$ as catalyst depends on micro-emulsification between heterogeneous phases of solid catalyst and immiscible liquid phases(Banković-Ilić et al., 2017; Halder et al., 2014; Patel \& Sankhavara, 2017; Takase et al., 2015). Since transesterification is reversible in nature and forward path of -reaction is always desirable for achieving higher product yield (Dhanasekar et al., 2019; Madhu et al., 2016). Parameters of process such as oilmethanol mole ratio, catalyst-concentration and temperature of reaction temperature have great influence on the product yield.

3.1 Oil-methanol mole ratio effect

Stoichiometrically, 3 moles of $\mathrm{CH}_{3} \mathrm{OH}$ require for 1 mole FAME production. Excess methanol may require to maintained forward path of reaction (Banković-Ilić et al., 2017; Patel \& Sankhavara, 2017). Experiments were performed using oil-methanol moleratio of 1:4, 1:6, 1:8 and 1:10 and catalyst-concentration of $2 \%$ and temperature of reaction as $60^{\circ} \mathrm{C}$ was kept constant for all experiment runs and results are dissipated in Figure 2.

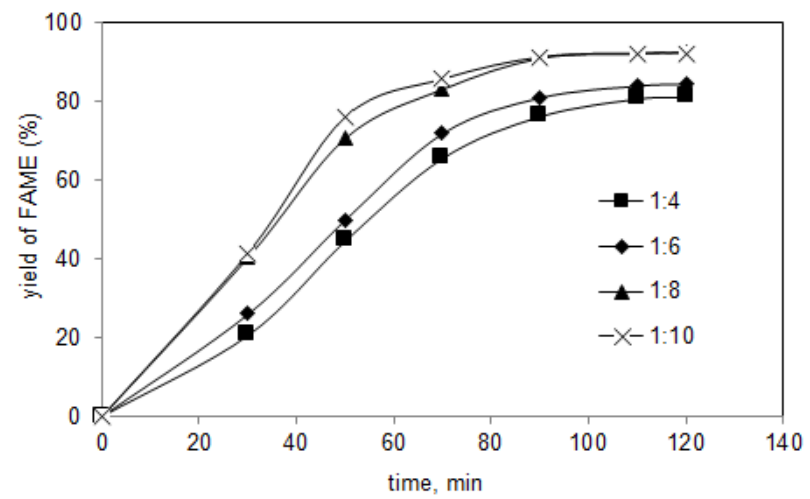

Figure 2: Effect of oil-methanol mole-ratio FAME yield

It has been observed that FAME yield was increasing with increase in oil-methanol mole-ratio 1:4-1:8 with further rise in mole-ratio has marginal incremental effect of FAME yield. Hence, 1:8 molar ratio was considered as optimum for further experimental investigations. The initial increase in product yield with mole-ratio may be attributed that the higher moles are favorable to keep the forward-path of reversible-reaction. Higher molar ratio than optimum value is not favorable, glycerol produced as side product during reaction may mix in surplus methanol and reaction- can be reverted. It may lead to decrease in yield of desired product. Separation of methanol from final product increase the downstream processing cost (Banković-Ilić et al., 2017; Harsha Hebbar et al., 2018; Kavitha et al., 2019; Madhu et al., 2016). Hence, too methanol is not recommended for synthesis of fatty acids methyl esters.

\subsection{Catalyst-concentration effect}

Study of catalyst-concentration effect on FAME synthesis is important to avoid the separation of catalyst from the final product. Excessive catalyst concentration may hinder rate of reaction. Higher concentration reduced the emulsification rate between the heterogeneous phases involved in reaction mixture (Dhanasekar et al., 2019; Harsha Hebbar et al., 2018; Kavitha et al., 2019; Madhu et al., 2016). Stirring may not able to maintain desire emulsification rate.

Experiments were performed varying concentration of catalyst as 1,2 and 3\% weight of catalyst/weight of oil (w/w) and results have been shown in Figure 4. FAME yield increased with time and catalyst-concentration. It has been seen that product yield increase with rise in catalyst-concentration from 1 to $2 \% \mathrm{w} / \mathrm{w}$, additional rise in catalyst-concentration does not yield substantial increase in FAME yield. Hence 2\% catalyst concentration optimum for further investigation. 


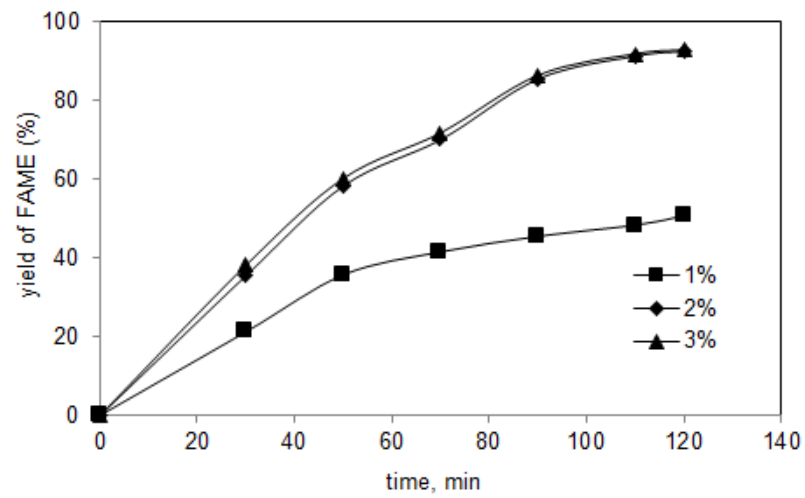

Figure 3 Effect of catalyst-concentration on FAME yield

Activity of catalyst is mainly related with basic strength and increase with catalyst loading till optimum value. Studies in literature reported that $\mathrm{Mg} / \mathrm{Cl}$ catalyst loading surpass outside an optimal value then catalyst activity diminish due to development of newer feebler basic sites. The increase in FAME yield observed to optimum catalyst loading, higher loading can attribute to likely formation of agglomerate catalyst particles (Harsha Hebbar et al., 2018; Kavitha et al., 2019). One important point to note here that additional catalyst use may require more energy for separation process. Hence, optimum-catalyst selection is desirable. Work on trans-esterification of soybean-oil in $\mathrm{CaO}$ presence shown $100 \%$ conversion of soybean was observed for catalyst loading of 3\% (w/w) (Takase et al., 2015). They also reported that $\mathrm{CaO}$ use as heterogeneous- catalyst reduce downstream processing requirement for catalyst separation from final product.

3.3 Reaction- temperature effect

Reaction- temperature effect on trans-esterification was investigated using varying reaction- temperature as $40^{\circ} \mathrm{C}, 50^{\circ} \mathrm{C}, 60^{\circ} \mathrm{C}$ and $65^{\circ} \mathrm{C}$ at previously optimize catalyst concentration as $2 \%(\mathrm{w} / \mathrm{w})$ and mole- ratio of oil-methanol as 1:8. Reaction- temperature effect on FAME yield has been shown in Figure 4. FAME yield increased with increase in reaction- temperature $40-60^{\circ} \mathrm{C}$, with further increase in temperature to $65^{\circ} \mathrm{C}$ shown marginally decrease FAME yield.

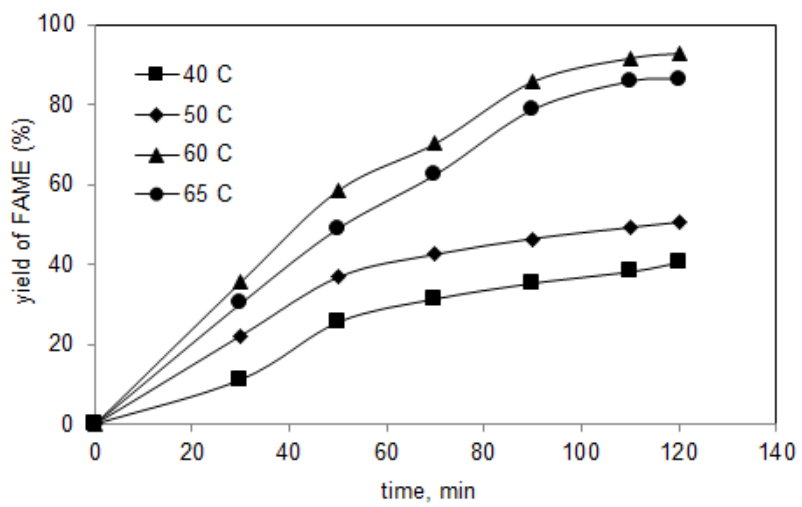

Figure 4: Reaction temperature effect on FAME yield

The optimize results fatty acids methyl esters from Karanja using calcium oxide shown in Table 3.

Table 3 Optimized result

\begin{tabular}{|l|l|}
\hline Parameter & Value \\
\hline Reaction Temperature $\left({ }^{\circ} \mathrm{C}\right)$ & 60 \\
\hline Catalyst-Concentration $\left(\% \mathrm{wt} \mathrm{wt}^{-1}\right)$ & 2 \\
\hline Oil-methanol mole-ratio & $1: 8$ \\
\hline Reaction- time (min) & 100 \\
\hline
\end{tabular}

Table 3 shows that reaction time required for synthesis is marginally higher compare to homogenous alkali catalyst. Most of the studies shown that reaction time for homogenous catalyst biodiesel synthesis is 60 to $90 \mathrm{~min}$. The marginally higher reaction time required due to kinetics for heterogeneous nature of reaction. However, there are considerable advantageous of heterogeneous 
catalyzed reaction such as lesser downstream processing requirement for separation of catalyst from final product and lesser wastewater generation improving quality of product.

\section{Conclusions}

Fatty acids methyl ester was obtained from non-edible feedstock from Karanja oil. Heterogeneous catalyst calcium oxide is explored as potential heterogeneous catalyst for synthesis of FAME. There was marginal higher molar ratio required for synthesis compared to conventional alkaline homogenous catalyst. Major advantageous of using heterogenous catalyst reduced the downstream processing for separation of catalyst from final product and wastewater generation for enhancing purity product was considerable product. The outcome of this study showed novel technique for synthesis of valuable product fatty acids methyl esters. Experimental protocol developed in present work can be explore as new and innovative path to synthesis FAME in forthcoming.

\section{References}

Banković-Ilić, I. B., Miladinović, M. R., Stamenković, O. S., \& Veljković, V. B. (2017). Application of nano CaO-based catalysts in biodiesel synthesis. Renewable and Sustainable Energy Reviews, 72, 746-760. https://doi.org/10.1016/j.rser.2017.01.076

Colombo, K., Ender, L., \& Barros, A. A. C. (2017). The study of biodiesel production using $\mathrm{CaO}$ as a heterogeneous catalytic reaction. Egyptian Journal of Petroleum, 26(2), 341-349. https://doi.org/10.1016/j.ejpe.2016.05.006

Dhanasekar, K., Sridaran, M., Arivanandhan, M., \& Jayavel, R. (2019). A facile preparation, performance and emission analysis of pongamia oil based novel biodiesel in diesel engine with CeO2:Gd nanoparticles. Fuel, 255, 115756. https://doi.org/10.1016/j.fuel.2019.115756

Halder, P. K., Paul, N., \& Beg, M. R. A. (2014). Prospect of Pongamia pinnata (Karanja) in Bangladesh: A Sustainable Source of Liquid Fuel. Journal of Renewable Energy, 2014, 1-12. https://doi.org/10.1155/2014/647324

Harsha Hebbar, H. R., Math, M. C., \& Yatish, K. V. (2018). Optimization and kinetic study of CaO nano-particles catalyzed biodiesel production from Bombax ceiba oil. Energy, 143, 25-34. https://doi.org/10.1016/j.energy.2017.10.118

Kavitha, V., Geetha, V., \& Jacqueline, P. J. (2019). Production of biodiesel from dairy waste scum using eggshell waste. Process Safety and Environmental Protection, 125, 279-287. https://doi.org/10.1016/j.psep.2019.03.021

Madhu, D., Chavan, S. B., Singh, V., Singh, B., \& Sharma, Y. C. (2016). An economically viable synthesis of biodiesel from a crude Millettia pinnata oil of Jharkhand, India as feedstock and crab shell derived catalyst. Bioresource Technology, 214, 210-217. https://doi.org/10.1016/j.biortech.2016.04.055

Patel, R. L., \& Sankhavara, C. D. (2017). Biodiesel production from Karanja oil and its use in diesel engine: A review. Renewable and Sustainable Energy Reviews, 71, 464-474. https://doi.org/10.1016/j.rser.2016.12.075

Petroleum Planning and Analysis Cell All India Study on Sectoral Demand of Diesel \& Petrol. (2013).

Takase, M., Zhao, T., Zhang, M., Chen, Y., Liu, H., Yang, L., \& Wu, X. (2015). An expatiate review of neem, jatropha, rubber and karanja as multipurpose non-edible biodiesel resources and comparison of their fuel, engine and emission properties.

Renewable and Sustainable Energy Reviews, 43, 495-520. https://doi.org/10.1016/j.rser.2014.11.049

White Paper on Alternative Fuels for Vehicles Vision \& Recommendations Alternative Fuels in India. (2019). March.

\section{Biographical notes}

Dr. Vitthal L. Gole is an Associate professor in the Department of Chemical Engineering, MMMUT, Gorakhpur India. He has more than 17 years of teaching and research experience. His main areas of research are Process Intensification, Sonochemistry, Advanced Oxidation Process.

Aditya Gupta: is B.Tech chemical engineering student in chemical engineering department, MMMUT.

Maharshi Yadav; Received M. Tech. in Environmental Engineering fromMMMUT, Gorakhpur India in 2018 and Pursuing PhD in Chemical Engineering from MMMUT respectively. His main area of research is Environmental flow assessment, Noise pollution, Environmental monitoring and assessment, Water disinfection and treatment. 